\title{
Coal seam gas: a space-based perspective
}

\begin{abstract}
Coal seam gas and other unconventional gas industries have often struggled to develop a social licence to operate with surrounding communities, frequently resulting in the emergence of broad opposition coalitions and legal challenges. In the present paper, the authors explore the relational aspects of coal seam gas's space-based setting with reference to Keith Halfacree's three-fold model of rural space. Applying this model to coal seam gas development in the New South Wales Hunter Valley, we argue that it is only by understanding so-called total space that efforts can be undertaken to promote the more inclusive stakeholder collaboration, which is a prerequisite for achieving shared value for industry and society.
\end{abstract}

Keywords space; social licence; shared value; coal seam gas; Hunter Valley, New South Wales

\section{Introduction}

In the mid-1990s, the commercial production of coal seam gas (hereafter also CSG) in Australia began in Queensland's Bowen and Surat Basins. ${ }^{1}$ Over the ensuing decades the industry grew to the point where exploration and/or extraction licences existed in multiple states and, in addition to providing supply for 25 per cent of the east coast energy market in 2009 (Witt et al., 2018), Australia's unconventional gas reserves (about four per cent of the global total) were seen as having considerable export opportunities (Canavan, 2018). In spite of its rapid growth, the industry has had an often-contentious relation with host populations. This contestation has led many authors to advocate for discussions around ensuring CSG's social licence to operate (Curran, 2017; Lacey \& Lamont, 2014; Luke, 2017; Luke et al., 2018; Paragreen \& Woodley, 2013). Notions of relational space and place are an important part of such discussions because of the recognised heterogeneity of the rural communities that often host CSG operations.

Where CSG discussions have been concerned with notions of relational space it has tended to be from the point of view of place attachment and the potential for a loss of place attachment to impact negatively on the psychological well-being of community members. Luke et al.

\footnotetext{
${ }^{1}$ It is acknowledged that tentative moves to extract CSG in Australia began in Queensland in the 1970s (see Keogh, 2013; Scott, 2013)
} 
(2018, p.654) have argued that work of this kind is important for ensuring that 'consideration of connections to place, as well as (potential) impacts on personal and shared resources' is part of good policy development. In the present paper, we wish to build on this earlier scholarship and consider how CSG space is socially constructed. We will do so with respect to Keith Halfacree's three-fold model of rural space (Halfacree, 2007) as well as by drawing on a case study of CSG development in the Hunter Valley in New South Wales. We argue in line with sentiments expressed by Halfacree (2006) that a capitalist enterprise should not be seen to be separate from its space-based setting. Only by considering space in its totality, we suggest, can efforts be undertaken to promote the more inclusive stakeholder collaboration, which is a prerequisite for achieving shared value for industry and society.

\section{The networked place based perspective and the three-fold model of rurality}

The idea of space as a socially constructed phenomenon has a long history, beginning with pioneering work by Durkheim in The Elementary Forms of Religious Life, before progressing in the second half of the twentieth century to work by influential anthropologists including Lévi-Strauss and Bourdieu (Harvey \& Braun, 1996). In this period some human geographers began to consider the notion that space (or place) was more than a spatial construct (see Gregory, 2000). Theorists such as Massey, Harvey, Relph, Tuan and McDowell began to question the position of capitalism in wider spatial systems, and also how notions of rational scientific space may be lacking. Tuan (1977), by way of example, developed his work on the relationship between space and place on the basis of an argument that place cannot be marginalised in favour of an exclusive focus on geographical space.

The idea that single or multiple species of space may co-exist in a rural locality was a major determinant of Halfacree's three fold model of rural space. Halfacree (2007) was seeking to address a fundamental question: does the rural still exist as an entity in the global North (see also Halfacree, 1993, 2006)? With the presence of capitalism in rural areas accepted, Halfacree's threefold model is representative of a wider push towards notions of rural social constructionism and a recognition that an environment is made up of multiple forms of knowledge, meaning, and identity (Heley \& Jones, 2012). To achieve this aim, Halfacree developed a model that aimed to situate rural capitalism within the total rural (Halfacree, 2007). Basing his ideas on work by Lefebvre, who had earlier proposed a conceptual triad for understanding space (see Lefebvre, 1991), Halfacree proposed a threefold architecture for rural space encompassing the interrelated concerns spanning: 
1. rural localities inscribed through relatively distinctive spatial practices, linked to production and/or consumption activities;

2. formal representations of the rural such as those expressed by capitalist interests, cultural arbiters, planners or politicians; and

3. everyday lives of the rural, which are inevitably subjective and diverse, and with varying levels of coherence/fracture. They both take in and, to a greater or lesser extent, subvert the other categories. (Halfacree, 2007, p.127)

Implicit within the Halfacree model is the notion that human beings create space (see Halfacree, 2006). In rural Australia, capitalist interests have an important role to play in the formation of rural space. McManus et al. (2012) have, with respect to two farming communities in Lachlan and the Northern Tablelands, shown how a healthy agricultural sector has flow on effects throughout surrounding economies and communities. They observe that 'robust levels of ongoing engagement between farmers and town communities are important in maintaining rural populations and services along with both a strong local economy and environment' (McManus et al. 2012, p.20). Similar links between industry sector(s) and the maintenance of community wellbeing exists in many Australian regions (see Anwar McHenry, 2009; Hajkowicz et al., 2011; Tonts et al., 2012).

As Lefebvre (1991, p.16) has argued, 'the space of the everyday activities is a concrete one, which is to say, subjective ... Lived space bears the stamp of the conflict between an inevitable, if long and difficult, maturation process and a failure to mature that leaves particular original resources and reserves untouched'. The maturation of space in a region such as the Hunter Valley, which we are discussing, brings the various components of Lefebvre's and Halfacree's trialetic into contact. With reference to the merging of material and ideational elements, none of the components of Halfacree's trialetic model of rural space can exist independently of each other. The level of congruence between different components of the rural can serve as a barometer for determining the level of structural coherence (or harmony) that exists in a rural setting. With respect to levels of coherence, Halfacree (2007) notes that spaces may be either: congruent and unified; contradictory and disjointed; or chaotic and incoherent. Where spaces are contradictory or chaotic one can observe increasing levels of contestation to establish the credentials of new ways of thinking. The so-called "trial by space", which also draws on the earlier work of Lefebvre, is used by Halfacree (2007) to observe how space is recast by new modes of production. 
Lefebvre (1991, p.417) has also argued that 'ideas, representations or value which do not succeed in making their mark on space ... will lose all pith and become mere signs, resolve themselves into abstract descriptions, or mutate into fantasies'. This is not to suggest that the history of a place is unimportant. Massey (1995, p.183) has observed that rather than there being a level of disconnect between the past and the present, the past is instead an embodiment of the 'real character of the place'. Such an idea of realness can be manipulated by industry into the creation of fictive place, as has been demonstrated in work by Overton and Murray (2016). As Overton and Murray acknowledge, all fictive places involve a combination of the material and the imagined. The marketing of the wine industry, by way of example, includes material elements related to topography, soil and the like. However, it also includes socio-cultural claims as wine businesses make appeals to consumers, which draw on 'the long and supposedly immutable wine making traditions of a region' (Overton \& Murray, 2016, p.6). The ability to frame a place discursively as a social construct has been recognised by McManus and Connor (2013, p.181) who noted that the 'rural is a term that is now part of a new politics of the land with reflexively constructed scripts deployed in conflicts with competing industries'.

Scripts are particularly important for the present discussion in the sense that different stakeholders in the Hunter Valley and other rural regions that play host to CSG development will variously invoke a range of arguments surrounding their future ideal for the area. McManus and Connor (2013) have argued that scripts will articulate socially constructed arguments that suggest the appropriateness (or not) of particular industries in a rapidly evolving regional patchwork. Silvasti (2003a and 2003b in Vanclay \& Enticott, 2011, p.259) has defined scripts as 'learned or socially conditioned mental maps that represent sets of rules, values, behavioural patterns and expectations that are determined by society'. In the mining sector, Dougherty and Olsen (2014) have recently argued that businesses are coming to see the value in adapting their corporate social responsibility (CSR) efforts to meet local conditions. However, the social context that a business is adhering to is, constantly in a state of flux; this returns to Massey's arguments, where, as suggested by Anderson (2008), space is always in a state of becoming, 'constantly disconnected by new arrivals, constantly waiting to be determined ... by the construction of new relations' (Anderson, 2008, p.231).

Massey (2005) has defined place in terms of a series of bundles in which individuals are drawn together by a series of cognitive and emotional processes, which are evolving and context specific. 'Temporary constellations' (Massey, 2005, p.141) will emerge as 
stakeholders align themselves to particular viewpoints on a place management question. An example of this phenomenon in CSG debates in Australia can be seen in the alignment of right wing radio announcer Alan Jones with what would normally be seen as leftist causes in support of farmers' rights to resist the encroachment of mining businesses onto their lands (Sharwood, 2015). Thinking beyond the evolution in the alignment of an individual stakeholder to particular place based debates, Calvert (2015) has articulated how energy geographies are also mediated by the interplay of both supply and demand forces. Export opportunities coupled with the arrival of new technologies are making the extraction of unconventional gas an economic and technical possibility. To date, however, the relationship of unconventional gas providers with other rural stakeholder groups has often remained transactional and adversarial (Bec et al., 2016; Hales \& Larkin, 2018; Sherval, 2018).

\section{Coal seam gas}

Along with shale gas and tight gas, coal seam gas represents a new unconventional energy reserve in countries such as Australia, China, Russia, the United States, and South Africa (Evensen \& Stedman, 2017). The Commonwealth Scientific and Industrial Research Organisation (CSIRO) in Australia has defined CSG as 'a form of natural gas, typically extracted from coal seams at depths of 300-1000 meters. It is a colorless, odorless, non-toxic mixture of a number of gases but mostly made up of methane (generally 95-97 per cent pure methane)' (CSIRO, 2012, in Preston, 2014, p.382). Recent scholarship on shared value and the unconventional gas sector has sought to highlight the mixed record of the industry with respect to their engagement with social and environmental issues, and also its potential to contribute enormous wealth to regional and national economies (see Hidalgo et al., 2015; Porter et al., 2015). In the United States unconventional gas has been estimated to likely account for 64 per cent of total gas production by 2020 (American Petroleum Institute, 2015). By 2020 it has been estimated that direct value add from unconventional gas and oil development in the United States will reach more than US\$255,000 million (Porter et al., 2015). In Australia, Delloite Access Economics (2012) have estimated that in 2010 production of CSG in Australia was 221 Petajoules out of approximately 48,800 Petajoules of total proven or known CSG reserves on Australia's east coast (Mazzarol, 2013). Australian export earnings from liquefied natural gas in 2013 totalled more than AU\$16.4 billion (Natural Coal Seam Gas, 2015). 
As a recognised industry in Australia, CSG extraction is a product of the late twentieth century when companies first experimented with the recovery of gas from underground coalmines. Originally forming part of safety related mine drainage activities, subsequent technological developments around hydraulic fracking (that is, the insertion of water, sand and/ or chemicals into rock formations at high pressure to release the gas inside) made the commercial extraction of gas feasible in the late 1990s in locations including the Bowen and Surat Basins in the Australian state of Queensland. For many years CSG has been a controversial topic in the Australian state of New South Wales with operators and government encountering broad opposition coalitions and legal challenges to CSG approvals (Preston, 2014; Turton, 2017). At the time of writing, rising energy prices in New South Wales and a number of other Australian states have drawn into focus the role of CSG in domestic energy production (Hannam, 2017). Simultaneously, however, the sustainability of the industry has been brought into question by the withdrawal (or planned withdrawal) of major players such as Australian Gas Limited (AGL) from active CSG exploration and extraction in regions including Camden (in south western Sydney) and the Hunter region around Gloucester (Slezak, 2016). The other major industry player, Santos, has also moved to re-categorize its Narrabri gas project in the state's north as "non -core", a move that some have speculated may mean that the project is under threat (Hannam, 2017).

For a number of years, commercial exploration and extraction of CSG in Australia has had an uneasy relationship with the local communities in many parts of rural Australia. While Marcos-Martinez et al. (2019) have identified the potential for CSG development to have a positive effect on regional family income levels, they have also noted that a range of regulatory and social factors may constrain unconventional gas extraction at local levels. Local community action groups (for example, the Lock the Gate Alliance) have formed on the basis of community scepticism over the rights of the gas industry to access privately owned farming land (Hepburn, 2012, 2013). According to Ransan-Cooper et al. (2018) what holds such groups together is a mixture of emotions connected to participants' perspectives of place: 'from love of place; anger, fear and distress at the idea of CSG development and its associated risks; to feelings of betrayal and frustration at the sense of disrespect from authority figures' (Ransan-Cooper et al., 2018, p.651).

The importance of the idea of a social licence for unconventional gas extraction is growing. Unlike the coal mining industry, which can draw upon generations of mining (usually underground rather than open cut mining) and contributions to communities, CSG is a 
relatively new industry. To manage its lack of a historically informed license to operate in the community, firms including Santos Energy have moved to propagate ideas that 'CSG has been with us since Australia's coal mining industry began over 100 years ago' (Santos, 2016, np). Such assertions form part of an attempt by industry to establish a social license both in the mining regions and more generally with the Australian public (see also Michell \& McManus, 2013). CSG has indeed been naturally present in mines in the Hunter Valley and elsewhere since their initial formation. More recently, while the technology now exists too commercially extract gases from underground coal seams, the pluralistic characteristics of many rural areas has created a complex problem for policy makers. CSG and other unconventional gas forms are entwined with larger debates over the roles of different energy sources and climate change (Lyster, 2013; Mercer et al., 2014). At the more local level Evensen and Stedman (2017, p.9) have called for policy makers to 'recognise the importance of less straightforward and more subjective impacts'.

\section{Relational space (or place) and CSG in the Hunter Valley}

The International Mining for Development Centre (2014) has observed that in order to achieve the dual socio-economic development outcomes from the creation of shared value, an underlying requirement of industry must be recognition of the broadest possible range of stakeholders and development of effective stakeholder communication strategies. Freeman (1984, p.46) once defined a stakeholder as 'any group or individual who can affect or is affected by the achievement of the organisation's objectives'. Stakeholders, including government and NGOs, are essential for achieving shared value outcomes in relation to unconventional gas extraction (Hidalgo et al., 2015). Achieving positive outcomes for different stakeholders and creating economic value do not have to be mutually exclusive. At the same time, however, stakeholder interests do not exist in isolation. The Queensland Government made the following observation in debates on a bill for governing landholder's rights to refuse gas and coal exploration on Crown property:

There are sound policy reasons why landholders do not have a power of veto with regards to resource development on their land ... Resources are owned by the people of Queensland and their development benefits all Queenslanders through provision of jobs and payment of royalties and other taxes ... The shared value resources bring to the state means the decision to develop the resources is taken out of private hands and rests 
with the Government on behalf of all Queenslanders. (Queensland Government, 2015, np)

Whatever the merits of such argument are, it shows the complex interplay of temporal and geographic forces in a pluralistic rural setting. Like other State and Commonwealth Governments in Australia, the Queensland Government has both the right to override landholder interests to pursue high value sub surface resources (Select Committee on Unconventional Gas Mining, 2016), and the responsibility to adjudicate between conflicting interests when contestation occurs (see Alfredson, 1987). Rural landholders are both residents of a state of Australia and - in the case of regions such as the Darling Downs - current custodians of environments and places. Historically, mining companies have sometimes sought to devalue the legitimacy of certain stakeholder positions. For example, Metgasco management has described local groups protesting against an exploration license granted in the northern New South Wales town of Bentley as 'activists who defied common sense and were not accountable for the welfare of the region' (Arashiro, 2017, p.6).

Kohne and Rasch (2019) have argued that those living near fracking sites will often seek to mobilise against a development on the basis of perceived local impacts. Communities are also often locked out of decision making processes, leading to acts of resistance that include seeking to preclude mining companies from accessing land either through direct action or through the courts. As McCreaae et al. (2019) have noted, in both industry and government notions of trust will drive community resilience and well-being in CSG regions. Trust will form on the basis of interlinkages that exist in a community, and, with this tendency in mind, we next explore the various temporal and geographic aspects of space in the Hunter Valley with reference to Halfacree's threefold model.

\section{The Hunter Valley}

McManus (2016, p.257) has identified the physical locality of the Hunter Valley as 'a water catchment of the Hunter River, which rises in the Barrington Tops and generally flows southwest to enter the Pacific Ocean at what is now the city of Newcastle ... the catchment is approximately 21,500 square kilometres in area' (figure 1). Located approximately two hours' drive north of Sydney on the Australian East Coast, the Hunter Valley includes both northern and southern administrative regions (see McManus, 2008). Home to Indigenous peoples for thousands of years and first settled by Europeans in the 1780s, the region has progressively taken on the characteristics of a patchwork economy encompassing a range of 
industries including thoroughbred breeding, viticulture, and associated wine tourism, dairy farming, and open cut and underground coal mining (Connor et al., 2008; Cottle, 2013; McManus, 2008; McManus et al., 2011; Wearing et al., 2014; Winchester et al., 2000).

Insert figure 1 about here

\section{Reading relational CSG space in the Hunter Valley}

Each of the industries that now makes, or has made, up the industrial mix in the Hunter Valley is an example of historically situated spatial practices (the rural localities component in Halfacree's model). For thousands of years spatial practices have evolved to reflect changing physical landscapes as well as changes in society's expectations for land uses in sustainable regional development (McManus, 2008; McManus et al. 2014). As Lefebvre has argued, space is neither 'simply natural geography nor an empty container filled by history' (White, 2010, p.2). Rather, space is an ever-changing entity produced in society over time. To understand how production manifests we must recognise the inherently relational nature of space and, in particular, observe, as Lefebvre did, that 'the social relations of production have a social existence to the extent that they have a spatial existence; they project themselves into a space, becoming inscribed there, and in the process producing that space itself' (Lefebvre, 1991[1974], p.11).

Different representations of the rural (the second component of Halfacree's model) have been suggested by the various formal stakeholder interests with a stake in CSG development in the Hunter Valley. McManus and Connor (2013) have given voice to many stakeholders in the course of their discussions about stakeholder scripts in the Upper Hunter. Rather than revisiting the composition of these scripts here, we suggest that the salience of a stakeholder group's argument will be determined by its ability to link individual and collective interests to concerns held by members of a given, wider population. Hales and Larkin (2018, p.938) have, for instance, shown how those with tourism interests in the Scenic Rim south of Brisbane were able to link their businesses to the concerns held by members of the anti-CSG movement, thus avoiding a situation where environmental concerns are co-opted in 'neo liberal business-government relations'. In turn, Lai et al. (2017) have shown how, in Hunter Valley townships such as Gloucester, recent tourism growth has accompanied downturns in traditional forestry and agricultural activities, and affected the ways in which environments are represented and interpreted. Over time, then, the ways in which people, place, and environment are represented changes in response to industry diversification and associated 
shifts in government regulatory practices (Sherval, 2018). At the same time, political interests will seek to manage the growth of CSG initiatives using a range of instruments including New South Wales's much-debated strategical regional land use plans (Sherval \& Graham, 2013), brought in to 'support growth, protect the environment and respond to competing land uses, while also preserving key regional values over the next 20 years' (NSW Government Department of Planning and Infrastructure, 2012, p.8)

The strategic regional land use plans were necessary given the increasing realisation that CSG has a number of impacts on host populations. Della Bosca and Gillespie (2018) draw attention to the positive and negative impacts that changes in energy landscapes can have on community identity and cohesion elsewhere in New South Wales. Arguing that community attachment to place is built on a series of ecological, built, social, and symbolic foundations, Della Bosca and Gillespie demonstrate that 'factors of time and place can make community level actors within the energy landscape either receptive, or resistant to change' (p.734). In the Hunter Valley an increasing body of scholarship has sought to examine the impact of CSG and mining more generally on psychological well-being (Lai et al., 2017a; Lai et al., 2017b). McManus et al. (2014, p.64) have argued, in addition, that notions of solastalgiathe "pain or distress caused by the loss of, or inability to derive, solace connected to the negatively perceived state of one's home environment' (Albrecht et al., 2007, p.96) — tend not to sit comfortably with the positivist and scientific frames commonly employed in social impact assessment processes. These notions are, however, an important variable for those wishing to understand how trust in, and thus the social licence of, a mining operation may be formed (Moffat \& Zhang, 2014).

The third component of Halfacree's model (lives of the rural) are those 'diverse and often incoherent images and symbols ... associated with the tumults of space as directly lived; (Halfacree, 2006, p.51). Governments continue to respond to unconventional gas development using different formal mechanisms designed to manage risk in an increasingly fractured policy setting (Witt et al., 2018). Decisions by a community (or community member) to mobilise in support of or opposition to CSG will be made on the basis of personal emotions governed by the restrictions and opportunities afforded to them by the 'distinctly rural affective practices and social context' around them (Ransan-Cooper et al., 2018, p.650). Possessing the power to subvert the space-based perspectives espoused by capitalist and other interests (Halfacree, 2007), space-as-lived represents a moment-to-moment overlay of society on physical space. For Lefebvre (1991[1974], p.42) such space is alive: 'it speaks ... It 
embraces the loci of passion, of action and of lived situations, and thus immediately implies time'.

Sherval (2018, p.1) has argued that the 'unlikely alliances forming between environmentalists and farmers against the State [Government in New South Wales]' over CSG development are temporal in nature, and framed in terms of changing social relations with the material world. While one should not deny the longstanding connections of mining communities to the mining industry (Della Bosca \& Gillespie, 2018; Winchester et al., 2000), we cannot assume that such connections will not evolve on a case-specific basis. As demonstrated in the Ipswich City Council area (northwest of Brisbane), longstanding economic connections to mining can be pushed aside as local authorities seek to realign their community's futures: 'Even though we're a city with a proud mining history that it's time these activities are wound down and certainly in relation to coal seam gas exploration' (Tlozek, 2015, np).

While such moves are often not universally well received in the community (Tlozek, 2015), the challenge is that as an industry CSG is still subject to ongoing review over the nature of its impacts on society and the environment (Cui et al., 2018; Fleming \& Measham, 2015; Werner et al., 2018). In addition to being technologically new, it is also case-specific with respect to the interplay of different community stakeholder groups in discussions over best practice management. As Norman (2016, p.250) has argued with respect to CSG development in northwestern New South Wales; farmers, residents and environmentalists are being joined at the management table by Aboriginal groups who, for the first time since 1788, are being recognised for their role in ensuring 'wider community futures'.

\section{Conclusions}

Harvey and Bice (2014, p.330) have argued that for all the ambiguity that exists over the term social licence in the extractives sector, it is clear that social licence 'cannot be defined by regulation; it must be collaborative, be specific to individual operations and projects, and has to be based on a site's overall social performance on a continuously maintained basis'. To engage with any community and to establish an ongoing social licence requires that trust be developed and maintained through close collaboration with affected stakeholders. When trust is present there is the potential to create and enact shared value: "policies and operating practices that enhance the competitiveness of a company while simultaneously advancing the economic and social conditions in the communities in which it operates' (Porter \& Kramer, 2011, p.6). And there are at least three ways in which one can create shared value (Porter \& 
Kramer, 2011): first, reconceive products and markets; second, redefine productivity in the value chain; and third, enable local cluster development.

In addition, Harvey and Bice (2014, p.333) have argued that the creation of clusters is essential for extractive industries wishing to create trust; they advocate that 'long life extractive operations should seek to broaden economic options around themselves in order to induce competitive supply, to lessen expatriate dependency and to share infrastructure costs. In short, they should aim to nucleate clusters of broader economic development'. While we do not disagree with the fundamental premise of this statement, in line with Preston (1975, p.446) we suggest that 'serious analysis of the corporation-society relationship requires rigorous and comprehensive conceptions of both the corporation and society; and these conceptions must be articulated in comparable, or at least translatable terms'.

We also argue that creating trust in genuine, ongoing relationships with local communities is inadequate. While 'business has the ability to deploy resources and management capability with a laser-like intensity' (Harvey and Bice, 2014, p.333), the focus on aligning social licence to operate with core business activities fails to acknowledge that extractive industries have network impacts. For example, burning fossil fuels creates negative climate change impacts in locations bereft of the benefits of this extractive process and located beyond the laser-like intensity of a business's focus. Similar logic applies with regard to other processes, including CSG extraction.

The wider community with which shared value purports to work is not static-either temporally or geographically (Porter in Hidalgo et al., 2015). This fluidity is similar to mining generally, because, as Harvey and Bice (2014, p.327) note 'while huge value from resource extraction accrues nationally and globally, the costs are most often borne disproportionally by people living local to resource operations'. This point is important for any industry wishing to establish a social licence to operate. This licence is a collective approval granted by a network of stakeholders ... meaning all individuals or groups who can affect a project or operation' and the primacy of a community, defined as 'those who are directly affected by a project or operation, carrying a stronger badge of legitimacy' (Harvey and Bice, 2014, p.330).

On the basis of the foregoing analysis, we argue that the relationship between networked space and CSG needs further research. As Duncan et al. (2018) have argued with respect to the thoroughbred industry in New South Wales, the danger in defining social licences to 
operate in relation to space is that industries can manipulate community sentiment by targeted contributions to local causes. When combined with the potential for even a well-planned community consultation process to marginalise specific groups in the community, there is the possibility that such groups will resort to protest because they feel that they are not participants in any meaningful dialogue. As we have shown here, the formation of space for CSG is as much about society's representations of that space as it is about distinct spatial practices. Creating trust relationships with communities is, then, a particular construction of space. Using Halfacree's threefold model of space, we show how the dialects between different aspects of space can be exposed, decoded, and read. With space contested via discursive, legal and various other means, critical readings of space are more vital than ever.

\section{References}

Albrecht, G., Sartore, G.-M., Connor, L., Higginbotham, N., Freeman, S., Kelly, B., . . Pollard, G. (2007). Sostalgia: The distress caused by environmental change. Australasian Psychiatry, 15(sup1), S95-S98.

Alfredson, I. (1987). Policy objectives of mining legislation and the Queensland review. Australian Mining and Petroleum Law Association Yearbook, Retrieved from http://www.austlii.edu.au/au/journals/AUMPLawAYbk/1987/7.pdf

American Petroleum Institute. (2015). Facts About Shale Gas. Retrieved from http://www.api.org/policy-and-issues/policy-items/exploration/facts_about_shale_gas

Anderson, B. (2008). For Space (2005): Doreen Massey. In P. Hubbard, R. Kitchin \& G. Valentine (Eds), Key Texts in Human Geography, London: SAGE, 227-235.

Anwar McHenry, J. (2009). A place for the arts in rural revitalisation and the social wellbeing of Australian rural communities. Rural Society, 19(1), 60-70.

Arashiro, Z. (2017). Mining, social contestation and the reclaiming of voice in Australia's democracy. Social Identities, 23(6), 661-673.

Bec, A., Moyle, B. D., \& Char-lee, J. M. (2016). Drilling into community perceptions of coal seam gas in Roma, Australia. The Extractive Industries and Society, 3(3), 716-726.

Calvert, K. (2015). From ‘energy geography’to ‘energy geographies' Perspectives on a fertile academic borderland. Progress in Human Geography, 40(1), 105-125.

Canavan, M. (2018). Media Release: Australian gas exports set to double, Asia to drive demand. Retrieved from 
https://www.minister.industry.gov.au/ministers/canavan/media-releases/australiangas-exports-set-double-asia-drive-demand

Connor, L., Higginbotham, N., Freeman, S., \& Albrecht, G. (2008). Watercourses and Discourses: Coalmining in the Upper Hunter Valley, New South Wales. Oceania, 78(1), 76-90.

Cottle, D. (2013). Land, life and labour in the sacrifice zone: The socio-economic dynamics of open-cut coal mining in the Upper Hunter Valley, New South Wales. Rural Society, 22(3), 208-216.

Cui, T., Moore, C., \& Raiber, M. (2018). Probabilistic assessment of the impact of coal seam gas development on groundwater: Surat Basin, Australia. Hydrogeology Journal, 26(7), 2357-2377.

Curran, G. (2017). Social licence, corporate social responsibility and coal seam gas: framing the new political dynamics of contestation. Energy Policy, 101(February), 427-435.

Della Bosca, H., \& Gillespie, J. (2018). The coal story: Generational coal mining communities and strategies of energy transition in Australia. Energy Policy, 120(September), 734-740.

Deloitte Access Economics. (2012). Advancing Australia Harnessing our comparative energy advantage. Retrieved from http://www.appea.com.au/wpcontent/uploads/2013/04/120625_DAEreportAPPEAfinal.pdf

Dougherty, M. L., \& Olsen, T. D. (2014). Taking terrain literally: grounding local adaptation to corporate social responsibility in the extractive industries. Journal of Business Ethics, 119(3), 423-434.

Duncan, E., Graham, R., \& McManus, P. (2018). 'No one has even seen... smelt... or sensed a social licence': Animal geographies and social licence to operate. Geoforum, 96(November), 318-327.

Fleming, D. A., \& Measham, T. G. (2015). Local economic impacts of an unconventional energy boom: the coal seam gas industry in Australia. Australian Journal of Agricultural and Resource Economics, 59(1), 78-94.

Freeman, E. (1984). Strategic management: A stakeholder approach. Boston: Pitman.

Gregory, D. (2000). Place. In R. J. Johnston, D. Gregory, G. Pratt, \& M. Watts (Eds.), The Dictionary of Human Geography (4th ed., pp. 582-584). Oxford: Blackwell Publishers.

Hajkowicz, S. A., Heyenga, S., \& Moffat, K. (2011). The relationship between mining and socio-economic well being in Australia's regions. Resources Policy, 36(1), 30-38. 
Hales, R., \& Larkin, I. (2018). Successful action in the public sphere: the case of a sustainable tourism-led community protest against coal seam gas mining in Australia. Journal of Sustainable Tourism, 26(6), 927-941.

Halfacree, K. (1993). Locality and social representation: space, discourse and alternative definitions of the rural. Journal of Rural Studies, 9(1), 23-37.

Halfacree, K. (2006). Rural space: constructing a three-fold architecture. In P. Cloke, . Marsden, \& P. Mooney (Eds.), Handbook of rural studies. London: SAGE, 44-62.

Halfacree, K. (2007). Trial by space for a 'radical rural': Introducing alternative localities, representations and lives. Journal of Rural Studies, 23(2), 125-141.

Hannam, P. (2017). 'Still cowboys': Why the rush to develop coal seam gas leaves communities wary. Sydney Morning Herald. Retrieved from http://www.smh.com.au/environment/still-cowboys-why-the-rush-to-develop-coalseam-gas-leaves-communities-wary-20170928-gyqkqc.html

Harvey, B., \& Bice, S. (2014). Social impact assessment, social development programmes and social licence to operate: tensions and contradictions in intent and practice in the extractive sector. Impact Assessment and Project Appraisal, 32(4), 327-335.

Harvey, D., \& Braun, B. (1996). Justice, nature and the geography of difference. Cambridge, Mass: Blackwell Publishers Wiley Online Library.

Heley, J., \& Jones, L. (2012). Relational rurals: some thoughts on relating things and theory in rural studies. Journal of Rural Studies, 28(3), 208-217.

Hepburn, S. (2012). Who owns coal seam gas in New South Wales (and who can stop it being mined)? Retrieved from https://theconversation.com/who-owns-coal-seam-gasin-new-south-wales-and-who-can-stop-it-being-mined-6969

Hepburn, S. (2013). Does Unconventional Gas Require Unconventional Ownership; An Analysis of the Functionality of Ownership Frameworks for Unconventional Gas Development. Pitt. J. Envtl. Pub. Health L., 8(1), 1-54. pages

Hidalgo, C., Peterson, K., Smith, D., \& Foley, H. (2015). Extracting with Purpose: Creating Shread Value in the Oil and Gas and Mining Sectors' Companies and Communities. Retrieved from http://sharedvalue.org/resources/report-extracting-purpose

International Mining for Development Centre. (2014). Shared value in energy and minerals sector: Australian context and implementation. In EMI Lunch and Learn Perth. Retrieved from https://im4dc.org/wp-content/uploads/2013/07/Shared-Value-inEnergy-and-Minerals-Sector.pdf 
Keogh, L. (2013). The first four wells: unconventional gas in Australia. M/C Journal, 16(2). Retrieved from http://journal.mediaculture.org.au/index.php/mcjournal/article/view/617

Kohne, M., \& Rasch, E. (2019). Hydraulic fracturing in rural communities: Local realities and resistance. In M. Scott, N. Gallent, \& M. Gkartzios (Eds.), The Routledge Companian to Rural Planning (pp. 557-565). Oxon: Routledge.

Lacey, J., \& Lamont, J. (2014). Using social contract to inform social licence to operate: an application in the Australian coal seam gas industry. Journal of Cleaner Production, 84(December), 831-839.

Lai, P.-H., Lyons, K. D., Gudergan, S. P., \& Grimstad, S. (2017). Understanding the psychological impact of unconventional gas developments in affected communities. Energy Policy, 101(February), 492-501.

Lai, P.-H., Lyons, K. D., Kyle, G. T., \& Kreuter, U. P. (2017). Coping with change in rural landscapes: The psychological stress of rural residents experiencing unconventional gas developments. Land Use Policy, 67(September), 487-497.

Lai, P.-H., Morrison-Saunders, A., \& Grimstad, S. (2017). Operating small tourism firms in rural destinations: A social representations approach to examining how small tourism firms cope with non-tourism induced changes. Tourism Management, 58(February), $164-174$.

Lefebvre, H. (1991). The production of space (Extracts) (Vol. 142). Oxford: Blackwell.

Lefebvre, H. (1991[1974]). The production of space (Vol. 142). Oxford: Blackwell.

Luke, H. (2017). Social resistance to coal seam gas development in the Northern Rivers region of Eastern Australia: Proposing a diamond model of social license to operate. Land Use Policy, 69(December), 266-280.

Luke, H., Brueckner, M., \& Emmanouil, N. (2018). Unconventional gas development in Australia: A critical review of its social license. The Extractive Industries and Society. 6(4), 648-662.

Lyster, R. (2013). Coal seam gas in the context of global energy and climate change scenarios.Environmental and Planning Law Journal. 29(2), 91-100. incomplete

Marcos-Martinez, R., Measham, T. G., \& Fleming-Muñoz, D. A. (2019). Economic impacts of early unconventional gas mining: Lessons from the coal seam gas industry in New South Wales, Australia. Energy Policy, 125(February), 338-346. 
Mazzarol, T. (2013). Coal Seam Gas and the future of manufacturing in Australia. Retrieved from http://theconversation.com/coal-seam-gas-and-the-future-of-manufacturing-inaustralia-18840

McCrea, R., Walton, A., \& Leonard, R. (2019). Rural communities and unconventional gas development: What's important for maintaining subjective community wellbeing and resilience over time? Journal of Rural Studies. 68(May), 87-99

McManus, P. (2008). Mines, wines and thoroughbreds: Towards regional sustainability in the Upper Hunter, Australia. Regional Studies, 42(9), 1275-1290.

McManus, P. (2016). Evolving Metabolic Relations: Nature, Resources and People in the Hunter Valley. In R. Dufty-Jones \& J. Connell (Eds.), Rural Change in Australia: Population, Economy, Environment (pp. 255-275). Burlington: Ashgate.

McManus, P., Albrecht, G., \& Graham, R. (2011). Constructing Thoroughbred Breeding Landscapes: Manufactured Idylls in the Upper Hunter Region of Australia. In S. Brunn (Ed.), Engineering Earth: The Impacts of Megaengineering Projects (pp. 1323-1329). Dordrecht, The Netherlands: Springer Science+Business Media.

McManus, P., Albrecht, G., \& Graham, R. (2014). Psychoterratic geographies of the Upper Hunter region, Australia. Geoforum, 51(May), 58-65.

McManus, P., \& Connor, L. (2013). What's mine is mine (d): Contests over marginalisation of rural life in the Upper Hunter, NSW. Rural Society, 22(2), 166-183.

McManus, P., Walmsley, J., Argent, N., Baum, S., Bourke, L., Martin, J., . . Sorensen, T. (2012). Rural Community and Rural Resilience: What is important to farmers in keeping their country towns alive? Journal of Rural Studies, 28(1), 20-29.

Mercer, A., de Rijke, K., \& Dressler, W. (2014). Silences in the boom: coal seam gas, neoliberalizing discourse, and the future of regional Australia. Ecology, 21(1), 222348.

Merrifield, A. (1993). Place and space: a Lefebvrian reconciliation. Transactions of the Institute of British Geographers, 18(4), 516-531.

Michell, G., \& McManus, P. (2013). Engaging communities for success: social impact assessment and social licence to operate at Northparkes Mines, NSW. Australian Geographer, 44(4), 435-459.

Moffat, K., \& Zhang, A. (2014). The paths to social licence to operate: An integrative model explaining community acceptance of mining. Resources Policy, 39(March), 61-70.

Natural Coal Seam Gas. (2015). A new export industry. Retrieved from http://www.naturalcsg.com.au/benefits/a-new-export-industry/ 
Norman, H. (2016). Coal Mining and Coal Seam Gas on Gomeroi country: Sacred lands, economic futures and shifting alliances. Energy Policy, 99(December), 242-251.

NSW Government Department of Planning and Infrastructure. (2012). Strategic regional landuse plan-Upper hunter. Retrieved from http://www.nsw.gov.au/sites/default/files/initiatives/upperhunterslup_sd_v01.pdf

Overton, J., \& Murray, W. E. (2016). Fictive place. Progress in Human Geography, 40(6), 794-809.

Paragreen, N., \& Woodley, A. (2013). Social licence to operate and the coal seam gas industry: What can be learnt from already established mining operations? Rural Society, 23(1), 46-59.

Porter, M., Gee, D., \& Pope, G. (2015). America's Unconventional energy Opportunity: A Win-Win for the Economy, the Environment, and a Lower-Carbon, Cleaner-Energy Future. Retrieved from http://www.hbs.edu/competitiveness/Documents/americaunconventional-energy-opportunity.pdf

Porter, M., \& Kramer, M. (2011). Creating shared value. Harvard Business Review, 89(1/2), $62-77$.

Preston, B. (2014). Unconventional Natural Gas in the Courts: An Overview. Journal of Energy \& Natural Resources Law, 32(4), 377-424.

Preston, L. (1975). Corporation and Society: The Search for a Paradigm. Journal of Economic Literature, 13(2), 434-453.

Queensland Government. (2015). Queensland Government submission - Landholders' Rights to Refuse (Gas and Coal) Bill 2015. Retrieved from file:///C:/Users/040391/Downloads/sub87.pdf

Ransan-Cooper, H., A. Ercan, S., \& Duus, S. (2018). When anger meets joy: how emotions mobilise and sustain the anti-coal seam gas movement in regional Australia. Social Movement Studies, 17(6), 635-657.

Scott, S. (2013). Coal seam gas in Queensland from there to where? In M. Mastalerz, M. Glikson, \& S. D. Golding (Eds.), Coalbed methane: scientific, environmental and economic evaluation (pp. 1-10). B.V.: Springer Science \& Business Media.

Select Committee on Unconventional Gas Mining. (2016). Interim Report. Retrieved from https://www.aph.gov.au/Parliamentary_Business/Committees/Senate/Gasmining/Gas mining/Interim_Report

Sharwood, A. (2015). Alan Jones, one of the left's biggest villains, has suddenly become a bit of a hero. How about that, eh? 21 January. Retrieved from 
http://www.news.com.au/national/queensland/alan-jones-one-of-the-lefts-biggestvillains-has-suddenly-become-a-bit-of-a-hero-how-about-that-eh/newsstory/150f7b0da68c0620c5d8ba139a303bbc

Sherval, M. (2018). Unlikely alliances in the battle for land and water securityunconventional gas and the politics of risk in NSW, Australia. In L. Loures (Ed), Land Use-Assessing the Past, Envisioning the Future, IntechOpen. Retreived from https://www.intechopen.com/books/land-use-assessing-the-past-envisioning-thefuture

Sherval, M., \& Graham, N. (2013). Missing the Connection: How SRLU Policy fragments landscapes and communities in NSW. Alternative Law Journal, 38(3), 176-180.

Slezak, M. (2016). AGL pulls out of coal seam gas across Australia, leaving farmers 'ecstatic'. Retrieved from https://www.theguardian.com/environment/2016/feb/04/agl-pulls-out-of-coal-seamgas-across-australia-leaving-farmers-ecstatic

Tlozek, E. (2015). Ipswich council to oppose future coal mines and CSG exploration. Retrieved from https://www.abc.net.au/news/2015-08-26/ipswich-council-to-opposefuture-coal-mines-and-csg-exploration/6727664

Tonts, M., Argent, N., \& Plummer, P. (2012). Evolutionary perspectives on rural Australia. Geographical Research, 50(3), 291-303.

Tuan, Y. F. (1977). Space and Place: The Perspective of Experience. Minneapolis: University of Minnesota Press.

Turton, D. J. (2015). Lawyers in Australia's coal seam gas debate: A study of participation in recorded community forums. The Extractive Industries and Society. 2(4), 809-812. Incomplete

Turton, D. J. (2017). Legal determinations, geography and justice in Australia's coal seam gas debate, In A. Lukasiewicz, S. Dovers, L. Robin, J. McKay, S. Schilizzi and S. Graham (Eds.) Natural Resources and Environmental Justice: Australian Perspectives, Victoria: CSIRO Publishing, 155-168.

Vanclay, F., \& Enticott, G. (2011). The role and functioning of cultural scripts in farming and agriculture. Sociologia Ruralis, 51(3), 256-271.

Wearing, S., Schweinsberg, S., Lai, P.-H., \& Lyons, K. (2014). A discussion of coal seam gas in Australia's hunter valley wine tourism region. Australasian Parks and Leisure, 17(2), 29-52. Incomplete? 
Werner, A. K., Watt, K., Cameron, C., Vink, S., Page, A., \& Jagals, P. (2018). Examination of child and adolescent hospital admission rates in Queensland, Australia, 1995-2011: A comparison of coal seam gas, coal mining, and rural areas. Maternal and child health journal, 22(9), 1306-1318.

White, R. (2010). What is spatial history. Spatial History Lab: Working paper [online] http://www. stanford. edu/group/spatialhistory/cgi-bin/site/pub. php.

Winchester, H., McGuirk, P., \& Dunn, K. (2000). Material and Symbolic Identities of Newcastle: Continuity and Change. In P. McManus, P. O'Neill, R. Loughran, \& O. R. Lescure (Eds.), Journeys: The Making of the Hunter Region (pp. 207-227). St Leonards NSW: Allen and Unwin.

Witt, K., Kelemen, S., Schultz, H., \& Vivoda, V. (2018). Industry and government responses to unconventional gas development in Australia. The Extractive Industries and Society, 5(4), 422-426. 